\title{
Keterlibatan Mahasiswa Dalam Aksi Bela Islam 212 di Jakarta
}

\author{
Leni Liberti', Erda Fitriani ${ }^{2}$, Eka Vidya Putra ${ }^{3}$ \\ 1,2,3 Universitas Negeri Padang \\ email: libertylenny2@gmail.com
}

\begin{abstract}
Abstrak
Penelitian ini bertujuan untuk menjelaskan dan mendeskripsikan keterlibatan mahasiswa dalam gerakan aksi bela Islam 212 di Jakarta. Penelitian ini dianalisis dengan menggunakan teori framing dalam study gerakan sosial yang dikemukakan oleh Snow dan Benford. Penelitian ini menggunakan pendekatan kualitatif dengan tipe penelitian studi kasus. Pemilihan informan dilakukan secara snowball sampling dengan jumlah informan 20 orang. Pengumpulan data dilakukan dengan cara observasi partisipasi pasif, wawancara mendalam, dokumentasi, serta validitas data dilakukan dengan triangulasi data. Data yang diperoleh dianalisis dengan menggunakan analisis interaktif seperti yang dikembangkan oleh Miles dan Huberman dengan langkah-langkah pengumpulan data, reduksi, penyajian dan kesimpulan. Hasil penelitian dari keterlibatan mahasiswa dalam aksi bela Islam 212 adalah; 1) bela $\mathrm{Al}$ - Qur'an, 2) bela Ulama, 3) kepemipinan, 4) diskriminasi hukum.
\end{abstract}

Kata Kunci: Aksi bela Islam 212, Gerakan sosial, Mahasiswa

This study aims to explain and describe the involvement of students in the 212 Islamic defense movement in Jakarta. This study was analyzed using framing theory in the study of social movements proposed by Snow and Benford. This study uses a qualitative approach to the type of case study research. The selection of informants was done by snowball sampling with the number of informants of 20 people. Data collection was carried out by passive participation observation, in-depth interviews, documentation, and data validity carried out by data triangulation. The data obtained were analyzed using interactive analysis such as those developed by Miles and Huberman with the steps of data collection, reduction, presentation and conclusions. The results of the study of student involvement in the Islamic defense act 212 were; 1) defend the Al-Qur'an, 2) defend Ulama, 3) leadership, 4) legal discrimination.

Keywords: The act of defending Islam 212, Social movement, Collegian 


\section{Pendahuluan}

Aksi bela Islam 212 di Jakarta dapat dikatakan sebagai gerakan sosial terbesar di abad milineal. Aksi bela Islam 212 sendiri dipicu oleh pernyataan Basuki Tjahaja Purnama atau Ahok terkait surat $\mathrm{Al}$ - Maidah $51^{1}$. Ahok yang seorang non-muslim dinilai tidak memiliki legitimasi untuk menterjemaahkan isi Al - Qur'an. Kasus ini bermula pada tanggal 27 September 2016, Basuki Tjahaja Purnama diduga menghina Al Qur'an yaitu surah Al Maidah [5]: 51 saat kunjungan kerjanya ke Pulau Pramuka yang berlokasi di Kepulauan Seribu. Aksi ini dikatakan terbesar karena jumlah massa yang mengikuti aksi bela islam tersebut diperkirakan mencapai jutaan, berdasarkan dari berbagai sumber media yang di dapat jumlah masyarakat dari berbagai kalangan

Aksi ini dikatakan terbesar karena jumlah massa yang mengikuti aksi bela islam tersebut diperkirakan mencapai jutaan, berdasarkan dari berbagai sumber media yang di dapat jumlah masyarakat dari berbagai kalangan. ${ }^{2}$ Berdasarkan data yang di dapat dari berbagai media online. Jumlah peserta aksi 212 mencapai sekitar 3,2 juta orang (okezone news), 5,5 juta orang (Republika.co.id), berkisar sekitar 7,5 juta orang (detiknews), dan sebanyak 22.000 personil polisi dikerahkan dalam mengawasi aksi ini. Dimana ribuan massa datang dari berbagai kalangan masyarakat Indonesia. Massa yang datang berkumpul di satu titik yang sama yaitu di halaman Monumen Jakarta. ${ }^{3}$

Penelitian ini bertujuan untuk menjelaskan dan mendeskripsikan "Keterlibatan Mahasiswa dalam Aksi Bela Islam 212". Permasalahan yang akan peneliti kaji adalah alasan yang mendorong mahasiswa terlibat dalam gerakan aksi 212. Keterlibatan mahasiswa ini jika dilihat jarak antara Padang dengan Jakarta tidak dekat, mereka pergi dengan resiko cukup besar tidak ada yang bertanggung jawab atas keselamatan mereka, ada kemungkinan hal - hal yang tidak diinginkan terjadi. Untuk sampai ke Jakarta harus berkorban tidak hanya secara fisik maupun materi dan meninggalkan segala aktivitas perkuliahan. Berdasarkan batasan masalah di atas, maka yang menjadi pertanyaan pada penelitian ini adalah: Apakah alasan mahasiswa terlibat dalam aksi bela Islam 212. Penelitian ini dianalisis dengan teori framing dalam study gerakan sosial oleh Snow dan Benford dianggap relevan dalam mengkaji alasan yang mendorong mahasiswa terlibat dalam aksi bela Islam 212. Asumsi dasar dari Teori framing atau proses penciptaan frame adalah untuk menjelaskan gerakan sosial atau aksi kolektif. Mereka berpendapat bahwa dalam gerakan sosial terjadi framing, atau lebih tepat gerakan sosial merupakan hasil suatu framing dan menghasilkan frame tertentu. Dalam gerakan sosial, frame diciptakan untuk memahami peristiwa dengan cara menyederhanakan dan menyarikan apa yang terjadi dan penyederhanaan ini bertujuan untuk memobilisasi pengangum dan pengikut, menuai dukungan dari penonton. Penelitian ini akan membahas hasil temuan dengan menggunakan salah satu peran utama yaitu motivational framing (menyediakan alasan untuk terlibat dalam gerakan bersama untuk memperbaiki situasi). Menurut Snow dan Benford adanya motivational framing dimana mahasiswa menyediakan alasan mereka untuk ikut terlibat dalam aksi bela Islam 212.

\footnotetext{
${ }^{1}$ Isi pernyataan Ahok pada tanggal 27 September 2016 dikutip melalui video youtube, jadi nggak usah pikirkan, ah...nanti kalo nggak kepilih pasti Ahok programnya bubar.nggak!. saya Ahok masih terpilih sampai Oktober 2017. Jadi jangan percaya sama orang, kan bisa aja dalam hati bapak - ibuk ngak pilih saya (Ahok) ya kan! dibohongin pake surat Al Maidah 51, macem-macem itu, itu hak bapak ibuk, jadi bapak ibu nggak bisa milih nih, karena saya bapak ibu takut masuk neraka, ngak apa apa. Karena ini panggilan hati bapak - ibuk . program ini (pemberian modal bagi budi daya kerapu) jalan saja. Jadi bapak ibuk ngak usah merasa ngak enak karena nuraninya ngak bisa pilih Ahok.
} 


\section{Metodologi Penelitian}

Penelitian ini dilakukan di Universitas Negeri Padang. UNP merupakan salah satu dari sekian banyak universitas yang ada di Sumatera Barat dimana mahasiswa nya terlibat dalam aksi bela Islam 212. Penelitian ini dilakukan dengan pendekatan kualitatif tipe studi kasus. Teknik pengambilan informan yaitu dengan snowball sampling ${ }^{4}$. Penarikan informan penelitian dilakukan yaitu suatu metode untuk mengidentifikasi, memilih dan mengambil sampel dalam suatu jaringan informan penelitian akan berkembang setelah dilapangan. Adapun kriteria informan adalah mahasiswa yang ikut terlibat lansung dalam aksi Bela Islam 212. Setelah melakukan penelitian informan berjumlah 20 mahasiswa yang terlibat aksi.

Teknik pengumpulan data yang dilakukan penelitian ini adalah dengan menggunakan observasi, wawancara, dan studi dokumentasi. Jenis observasi dalam penelitian ini adalah partisipasi pasif, dimana peneliti tidak terlibat langsung didalam objek penelitian. Partisipasi pasif, sewaktu pengumpulan data peneliti hanya menyaksikan, mengamati dan melakukan pengamatan langsung kelapangan tapi tidak ikut terlibat dalam kegiatan tersebut. ${ }^{5}$ Keterlibatan peneliti dengan para pelaku terwujud dalam bentuk keberadaan arena kegiatan yang di wujudkan oleh tindakan-tindakan pelakunya dan peneliti hanya mengamati aktivitas kehidupan sehari - hari mahasiwa, latar belakang serta lingkungan tempat tinggal mahasiswa tanpa ikut serta dalam aktivitas tersebut. Wawancara yang dilakukan peneliti adalah wawancara mendalam. Wawancara mendalam dilakukan kepada setiap informan yang dipilih dalam snowball sampling, pertanyaan yang diberikan kepada informan sesuai dengan pedoman wawancara yang telah disediakan. Untuk melengkapi data dokumentasi dilakukan dengan mengambil foto-foto, merekam suara, catatan harian observasi dan catatan harian wawancara terkait dengan keterlibatan mahasiswa dalam aksi bela Islam 212. Untuk menguji keabsahan data peneliti menggunakan teknik triangulasi data. Jenis triangulasi yang digunakan dalam penelitian ini yaitu triangulasi sumber dan triangulasi teknik. Data yang diperoleh di lapangan dianalisis mengacu pada model analisis interaktif yang dikembangkan oleh Miles dan Huberman yang terdiri dari tiga jalur analisis ${ }^{6}$ yaitu reduksi data, penyajian data dan penarikan kesimpulan.

\section{Hasil dan Pembahasan}

\section{Hasil}

Terkait besarnya partisipasi masyarakat dari berbagai dalam gerakan aksi bela Islam 212 menjangkau partisipan masyarakat yang luas. Melampaui batas DKI Jakarta sebagai fokus tempat dari diadakannya gerakan aksi bela Islam. Melihat jarak antara Padang dengan Jakarta tidak dekat, mereka pergi dengan resiko cukup besar tidak ada yang bertanggung jawab atas keselamatan mereka, ada kemungkinan hal - hal yang tidak diinginkan terjadi. Untuk sampai ke Jakarta harus berkorban tidak hanya secara fisik maupun materi dan meninggalkan segala aktivitas perkuliahan. Termasuk mahasiswa Universitas Negeri Padang menarik untuk melihat alasan yang mendorong mahasiswa ikut dalam gerakan aksi 212 . Adapun yang menjadi alasan mahasiswa terlibat dalam aksi bela Islam 212 adalah : Pertama bela $\mathrm{Al}$ - Qur'an mereka memahami bahwasannya Al - Qur'an merupakan suatu yang sakral karena isi yang terkandung dalam $\mathrm{Al}$ - Qur'an merupakan suatu firman Allah yang harus di junjung tinggi karena dijadikan sebagai pedoman dalam menjalani kehidupan.

\footnotetext{
${ }^{4}$ Burhan Bungin.2003.Data Penelitian Kualitatif. Jakarta. PT Rsaja Grafindo Persada. Hlm. 53

${ }^{6}$ Ibid, hlm. 20.
} 
Kedua, bela Ulama mereka memahami ulama mempunyai andil penting dalam Islam dan sangat melekat erat kaitannya dengan Al - Qur'an. Menurut mereka ulama harus dijaga untuk NKRI maksudnya disini karena Indonesia merupakan negara mayoritas Islam untuk itu keberadaan ulama sangat penting sebagai seorang penerus dakwah Islam dan pondasi Islam di Indonesia.

Ketiga, terkait kepemimpinan non muslim bahwa mereka tidak setuju dengan adanya pemimpin non muslim karena didasari beberapa alasan. Dalam $\mathrm{Al}$ - Qur'an telah di jelaskan bahwasannya umat Islam di pimpin oleh pemimpin yang sama keyakinan, dimana Indonesia merupakan salah satu negara masyarakatnya mayoritas beragama Islam alangkah baiknya jika di pimpin oleh pemimpin Islam pula. Selain itu adanya larangan bagi umat Islam melakukan serangkaian kegiatan terkait keagamaan. Tidak adanya toleransi yang dirasakan sehingga menambah ketidak setujuan untuk membiarkan pemimpin non-muslim dalam memimpin di negara Islam.

Keempat, diskriminasi hukum mereka memahami keberpihakan hukum di negara ini tidak adil. Hukum di negara ini memandang atau menyangkut dengan status, kekuasaan serta kekayaan yang dimiliki seseorang. Sehingga hal tersebut menyebabkan masih ada ketimpangan yang terjadi. Dalam beberapa kasus, diantaranya kasus penistaan agama oleh Ahok.

\section{Pembahasan}

Dalam teori gerakan sosial menawarkan framing atau proses penciptaan frame untuk menjelaskan gerakan sosial atau aksi kolektif. Mereka berpendapat bahwa dalam gerakan sosial terjadi framing, atau lebih tepat gerakan sosial merupakan hasil suatu framing dan menghasilkan frame tertentu. Dalam gerakan sosial, frame diciptakan untuk memahami peristiwa dengan cara menyederhanakan, menyarikan apa yang terjadi dan penyederhanaan ini bertujuan untuk memobilisasi pengangum dan pengikut, menuai dukungan dari penonton. Pada teori framing dalam study gerakan sosial bahwasannya ada tiga peran utama framing yaitu diagnostic framing (berperan mengidentifikasi masalah dan penyebab masalah tersebut) ,prognostic framing ( menawarkan kemungkinan solusi atas masalah atau rencana untuk menghadapi masalah.), dan motivational framing (menyediakan alasan untuk terlibat dalam gerakan bersama untuk memperbaiki situasi).

Dengan adanya frame Aksi bela Islam 212 ini peneliti menemukan framing lain yang didapat yang menjadi alasan keterlibatan mahasiswa UNP ikut terlibat dalam aksi bela Islam di Jakarta. Ke empat framing yang muncul menjadi frame aksi bela Islam 212 yang di bagi dua yaitu dilihat dari sisi keyakinan dan supermasi hukum diantaranya : a) Bela $\mathrm{Al}$ - Qur'an dimana adanya pemahaman yang tercipta dalam diri mereka bahwa Al -Qur'an merupakan bagian terpenting dalam agama Islam yakni sebagai pedoman kehidupan yang berisikan aturan - aturan tentang kehidupan. Al - Qur'an sangat dijaga keberadaannya karena merupakan (kalam) firman yang diturunkan lansung oleh Allah ke pada Nabi Muhammad SAW melalui perantara malaikat jibril. Dimana menurut pemahaman mereka sesuai dengan pemikiran Emile Durkheim terkait konsep agama adanya sesuatu yang profan(sesuatu yang di anggap biasa saja) dan sakral( sesuatu yang dianggap penting, di agungkan dan di junjung tinggi). b). Bela ulama mereka memahami bahwa Al - Qur'an dan Ulama merupakan suatu simbolik dari Islam yang saling memiliki keterkaitan ketika Ahok menistakan Al - Qur'an secara tidak lansung Ahok mencela ulama. Menurut mereka ulama harus dijaga untuk NKRI maksudnya disini karena Indonesia merupakan negara mayoritas Islam untuk itu keberadaan ulama sangat penting sebagai seorang penerus dakwah Islam dan pondasi Islam di Indonesia. c). Terkait kepemimpinan non muslim Melihat bagaimana pemahaman mereka tentang kepemimpin yang bukan muslim. Membawa mereka terlibat dalam gerakan aksi bela Islam di Jakarta. Mereka yang terlibat memahami negara yang mayoritas Islam. Sehingga pada aksi 
bela Islam terkait penistaan Ahok, mereka menginginkan bahwa sebaiknya di negara atau suatu daerah yang penduduknya mayoritas Islam ini di pimpin oleh pemimpin Islam juga. d. Diskriminasi hukum keterlibatan mereka dalam aksi bela Islam untuk menegakan hukum yang lebih adil di negara ini. Agar tidak ada ada keterpihakkan hukum dan negara terhadap orang tertentu, tetapi adil untuk seluruh rakyat Indonesia. Selain itu dalam kasus ini dengan adanya gerakan aksi bela Islam untuk segera mempenjarakan dan meproses hukum dengan cepat. Dengan adanya gerakan aksi dengan jumlah massa yang besar untuk melakukan penekanan dan pengkawalan sehingga cepat di penjarakan.

Dari keempat framing jika dapat di analisis dengan salah satu peran utama framing yaitu motivational framing atau alasan yang mendorong seseorang untuk terlibat dalam suatu gerakan bersama untuk memperbaiki situasi. Jadi keempat framing tersebutlah yang menjadi alasan mahasiswa untuk terlibat dalam gerakan aksi bela Islam 212 di Jakarta.

\section{Penutup}

Adapun yang menjadi keterlibatan mahasiswa dalam aksi bela Islam 212 adalah yaitu pertama membela Al - Qur'an, yang tercipta dalam diri mereka bahwa Al -Qur'an merupakan bagian terpenting dalam agama Islam yakni sebagai pedoman kehidupan yang berisikan aturan - aturan tentang kehidupan. yang kedua menurut mereka ulama harus dijaga untuk NKRI maksudnya disini karena Indonesia merupakan negara mayoritas Islam untuk itu keberadaan ulama sangat penting yang ketiga mereka menginginkan bahwa sebaiknya di negara atau suatu daerah yang penduduknya mayoritas Islam ini di pimpin oleh pemimpin Islam juga. serta adanya penegakkan hukum yang lebih adil. Peneliti mendeskripsikan tentang keterlibatan mahasiswa dalam aksi bela Islam212. Diharapakan dengan adanya penelitian ini, dapat menjadi pedoman penelitian tahap lanjut dari sudut pandang yang berbeda. Dalam keterlibatan mahasiswa dalam aksi bela Islam 212. Masih banyak fokus penelitian yang dapat diungkap salah satunya pengaruh keterlibatan mahasiswa dalam aksi terhadap pola pikir mahasiswa.

\section{Daftar Pustaka}

Bungin, Burhan. (2003). Data Penelitian Kualitatif. Jakarta: PT Rsaja Grafindo Persada. Mulyana, Deddy.(2010) Analisis Framing: Suatu Pengantar. Bandung. Situmorang, Abdul Wahab.(2007). Gerakan Sosial Studi Kasus Beberapa Perlawanan. Yogyakarta: Pustaka Pelajar. 